\title{
PENDEKATAN PSIKOLOGI DALAM STUDI ISLAM
}

\author{
Munawir Haris \\ Sekolah Tinggi Agama Islam Negeri (STAIN) Sorong Papua Barat \\ Email: Irfani.Fanani@gmail.com
}

\begin{abstract}
The present religious presence is required to be active in solving the problems and challenges facing its adherents. The position and role of religion is not only a symbol of piety but can play a role in solving the existing problems. The psychological approach in Islamic studies has a significant role to explain the outward symptoms of religious people. Armed with psychological theories will be easy to know the level of religion that is understood, lived and practiced by someone. The cognitive theory of religion is able to provide answers related to the limitations beyond human capabilities. In addition, religious-based psychotherapy is one concept of psychotherapy in the perspective of Islam that can be used as a therapy to cure various diseases both physical and mental disorders.
\end{abstract}

Keywords: Psychology, Religion, Islamic Studies

\begin{abstract}
Abstrak
Kehadiran agama saat ini dituntut aktif dalam memecahkan persoalan dan tantangan yang dihadapi para penganutnya. Posisi dan peran agama tidak sekedar menjadi lambang kesalehan tetapi dapat berperan dalam memecahkan persoalan yang ada. Pendekatan yang dilakukan dalam memahami agama untuk memecahkan persoalan manusia salah satunya adalah melalui pendekatan secara psikologis. Pendekatan psikologis dalam studi Islam mempunyai peran signifikan untuk menjelaskan gejalagejala lahiriah orang beragama. Berbekal teori-toeri psikologi akan mudah mengetahui tingkat keagamaan yang difahami, dihayati dan diamalkan seseorang. Dalam teori kognitif agama mampu memberikan jawaban berkaitan dengan keterbatasanketerbatasan diluar kemampuan manusia. Selain itu psikoterapi berbasis religious merupakan salah satu konsep psikoterapi dalam perspektif agama Islam yang dapat digunakan sebagai terapi penyembuhan berbagai penyakit baik fisik maupun gangguan mental.
\end{abstract}

Kata Kunci: Psikologi, Agama, Studi Islam

\section{PENDAHULUAN}

Pada abad keenam bangsa Cina dikenal sebagai bangsa yang memiliki keunggulan dalam ilmu pengobatan tradisional, astronomi, ramu-ramuan dan lain-lain. Pendek kata, saat itu Cina merupakan salah satu pusat peradaban dunia yang sangat maju. Karena itulah, Nabi Muhammad saw menganjurkan umat Islam agar menuntut ilmu di negeri Cina. Pada saat sekarang diakui atau tidak kiblat ilmu pengetahuan dan teknologi adalah bangsa Barat (Eropa dan Amerika). Mengacu pada anjuran Nabi agar umat Islam belajar sampai ke pusat peradaban Cina, maka pada saat sekarang umat Islam perlu belajar ilmu pengetahuan dan teknologi kepada bangsa Barat. Untuk menjadi umat yang maju dan kompetitif dalam arena pergulatan dunia, maka mau tidak mau umat Islam perlu menyadap ilmu tersebut. 
Salah satu disiplin ilmu yang berkembang pesat di kalangan masyarakat Eropa dan Amerika adalah Psikologi. Disiplin ilmu yang diakui sebagai disiplin ilmu yang mandiri pada tahun 1879 ini adalah ilmu yang lahir di Eropa dan saat ini berkembang pesat di Amerika. Dalam usianya yang melebihi angka satu abad ini psikologi telah memperlihatkan berbagai sumbangannya dalam memecahkan berbagai problem dan menyibak misteri hidup manusia sekaligus mengupayakan peningkatan sumber daya manusia. Melihat sumbangan psikologi yang demikian, jika kita ingin menjadi umat yang kompetitif, maka psikologi adalah disiplin ilmu yang harus dikuasai. Walaupun demikian disadari sepenuhnya bahwa psikologi adalah disiplin ilmu yang dibangun dan dikembangkan dalam masyarakat dan budaya Barat, maka sangat mungkin kerangka pikir (made of thought) psikologi dipenuhi pandangan atau nilai-nilai hidup masyarakat Barat yang tak jarang ditemui pandangan-pandangan psikologi berbeda bahkan bertentangan dengan pandangan Islam. Salah satu agenda penting yang harus diperhatikan oleh muslim yang mempelajari psikologi adalah meninjau kembali konsep-konsep psikologi dengan visi Islam. Hal ini bisa, dengan melakukan perbandingan ataupun dengan cara menilai psikologi dengan sudut pandang Islam atau psikologi dipakai sebagai pisau analisis masalah-masalah umat Islam.

Menurut Djamaludin Ancok, ${ }^{1}$ usaha yang dapat digunakan untuk mengintegrasikan psikologi dan Islam adalah membentuk konsep psikologi baru yang didasarkan pada Islam. Cara tersebut sangatlah bisa ditempuh mengingat kandungan al-Qur'an yang berpeluang membentuk suatu konsep psikologi yang berwawasan Islam. Islam melalui al-Quran, Sunnah Nabi dan ditambah dengan khazanah pemikiran Islam telah menyediakan bahan yang cukup untuk mengawali penyususnan suatu konsep psikologi Islam. Pada artikelnya, penulis akan membahas konsep perilaku beragama, mendialogkan antara psikologi dan Islam dan diakhiri dengan konsep baru tentang psikologi yang disebut dengan psikologi Islam.

\section{SEBUAH TELAAH ATAS KONSEP PERILAKU BERAGAMA}

Psikologi modern memberi tempat khusus bagi kajian tentang prilakuprilaku keagamaan dalam perkembangannya. Kajian-kajian seperti ini biasanya dapat kita temukan dalam buku-buku teks psikologi agama. Menarik untuk mencoba mengkaji ulang bagaimana psikologi modern (Psikoanalisis aliran prilaku, Psikologi Behaviorisme dan Psikologi Humanistik) tentang perilaku beragama ini.

${ }^{1}$ Djamaludin Ancok \& Fuat Nashori Suroso, Psikologi Islam, solusi Islam atas problemproblem psikologi, (Jakarta: Pustaka Pelajar, 2004), hal.3. 


\section{Psikoanalisis tentang perilaku beragama}

Sigmund Freud menggagas psikoanalisis, menerangkan manusia dengan teori tentang struktur kepribadian manusia. Tiga komponen yang termasuk dalam struktur kepribadian adalah Id, Ego dan Superego. ${ }^{2}$ Ketika manusia dilahirkan, ia hanya memiliki Id atau dorongan-dorongan yang minta dipuaskan. Dalam perkembangan selanjutnya tumbuhlah superego dalam diri manusia. Superego adalah nilai-nilai yang diterima individu dari lingkungannya. Antara Id dan Superego selalu muncul pertentangan. Id mewakili kepentingan pribadi sedangkan Superego mewakili norma-norma masyarakat. Untuk mengatur mekanisme diantara keduanya, berperanlah Ego.

Mencermati padangan Freud, maka dapat dikatakan bahwa dalam diri manusia tidak ada kebaikan yang bersifat alami atau biologis. Ketika lahir ia hanya memiliki nafsu/libido/id dan sama sekali tidak mempunyai dorongandorongan kebaikan atau hati nurani. Hati nurani yang mewakili nilai-nilai kebaikan lahir bersamaan dengan tumbuh kembangnya individu dalam masyarakat. Karena itu dalam pandangan Freud dorongan beragama bukanlah suatu dorongan yang alami atau asasi, melainkan dorongan yang tercipta karena tuntutan lingkungan. Agama adalah reaksi manusia atas ketakutannya sendiri. ${ }^{3}$ Dalam buku yang berjudul The Future of an Illusion, Freud menggungkapkan bahwa agama dalam ciri-ciri psikologisnya adalah sebuah ilusi, yakni kepercayaan yang dasar utamanya adalah angan-angan (Wishfulfillment). Manusia lari kepada agama disebabkan oleh ketidakberdayaannya menghadapi bencana (seperti bencana alam, takut mati, keinginan agar manusia terbebaskan dari siksaan manusia lainnya).

Dari penjelasan diatas dapat diungkapkan bahwa orang melakukan prilaku beragama semata-mata didorong oleh keinginan untuk menghindari keadaan bahaya yang akan menimpa dirinya dan memberikan rasa aman bagi dirinya sendiri. Untuk keperluan itu manusia menciptakan Tuhan dalam fikirannya. Tuhan yang diciptakannya sendiri itulah yang akan disembahnya. Sementara bagaimana ritual penyembahan terhadap Tuhan sangat tergantung dari contoh-contoh yang diperlihatkan oleh orang-orang terlebih dahulu yang melakukannya.

\section{Behaviorisme tentang perilaku beragama}

Behaviorisme (aliran prilaku) yang diilhami John Broadus Watson dan digerakkan B.F Skinner. Skiner berpendapat bahwa perilaku manusia pada umumnya dapat dijelaskan berdasarkan teori pengkondisian operan (operant conditioning). Manusia melakukan sesuatu dalam kehidupannya untuk mendapatkan akibat-akibat entah untuk pemenuhan kebutuhan atau

\footnotetext{
2 Jalaluddin, Psikologi Agama, (Jakarta: PT Raja Grafindo Persada, 2008), hal.202.

${ }^{3}$ Sigmund Freud dalam Psikologi Islam, solusi Islam..., hal.71.
} 
menghindari datangnya hukuman atau pengalaman yang tidak enak. Perilaku keagamaan sebagaimana prilaku lain merupakan ungkapan bagaimana manusia dengan pengkondisian operan belajar hidup di dunia yang dikuasai oleh hukum ganjaran dan hukuman.

Aliran ini memandang manusia ibarat mesin. Tingkah lakunya merupakan respon dari setiap stimulus yang didapatkan karena pelajaranpelajaran yang dipelajari. Oleh karena itu aliran ini sangat mementingkan lingkungan. Asumsi dasarnya bahwa tingkah laku manusia sebagai manifestasi kejiwaannya merupakan respon dari stimulus yang diterimanya dari lingkungan. ${ }^{4}$

Skiner menolak mekanisme internal dan eksternal untuk menjelaskan pengalaman beragama. Ucapan seperti "saya merasa suka pergi ke tempat ibadah" dipandang dari sudut pengertian Behavioristis tidak berbicara apaapa. Apakah perasaan menjadi penyebab orang pergi ke tempat ibadah atau Tuhan yang membangkitkan perasaan untuk pergi ke tempat ibadah itu? Masalah pokokny adalah orang yang bersangkutan mengetahui apa yang terjadi dengan orang yang merasa suka pergi ke tempat ibadah. Faktor pengalaman yang memuaskan itu mendorongnya pergi ke tempat ibadah dan tidak pergi ke tempat lain. Dalam pandangan Skiner kegiatan keagamaan diulangi karena menjadi faktor penguat sebagai perilaku yang meredakan ketegangan.

\section{Psikologi Humanistik tentang Perilaku beragama}

Tokoh yang diambil dalam kelompok ini adalah Abraham Maslow. Dalam pandangan Maslow semua manusia memiliki kecenderungan yang dibawa sejak lahir untuk mengaktualisasikan diri. Kita didorong oleh kebutuhankebutuhan yang universal dibawa sejak lahir, yang tersusun dalam suatu tingkatan dari yang paling lemah ke yang paling kuat. Prasyarat untuk mencapai aktualisasikan diri adalah memuaskan empat kebutuhan yang berada pada tingkat yang paling rendah yaitu kebutuhan fisiologi, kebutuhan rasa aman, kebutuhan memiliki cinta dan kasih sayang dan kebutuhan akan penghargaan. Aktualisasi diri dapat didefinisikan sebagai perkembangan yang paling tinggi dan penggunaan semua bakat perkembangan yang paling tinggi. Orang yang mengaktualisasikan diri didorong oleh metamotivasi (metamotivation).

Pendekatan humanistik mengakui eksistensi agama. Maslow sendiri dalam teorinya mengemukakan konsep metamotivation yang diluar kelima hierarchy of needs yang pernah dia kemukakan. Mystical adalah bagian dari metamotivation yang menggambarkan pengalaman keagamaan. Pada kondisi ini manusia merasakan adanya pengalaman keagamaan yang sangat dalam.

${ }^{4}$ Ramayulis, Psikologi Agama, (Jakarta: Kalam Mulia, 2007), hal.148. 
Pribadi (self) lepas dari realitas fisik dan menyatu dengan kekuatan transendental (self is lost and transcended). Menurut Maslow ini adalah keadaan tertinggi dari kesempurnaan manusia. Ada kesempatan dimana orang yang mengaktualisasikan diri mengalami ekstase, kebahagiaan, perasaan terpesona yang meluap-luap, suatu pengalaman keagamaan yang sangat mendalam.

Maslow menyebutkan peakers (transcended) yang memiliki wawasan yang jelas tentang diri mereka dan dunia mereka. Mereka cenderung lebih mistis, puitis dan saleh, lebih tanggap terhadap keindahan dan kemungkinan menjadi pembaharu dan penemu seperti Albert Schweitzer dan Albert Einsten, sedangkan kelompok non-peakers (non-transcended) cenderung menjadi orang yang praktis, berinteraksi dengan dunia secara efektif. Mereka cenderung menjadi pelaku, penguji kenyataan dan kognitif bukan emosional dan mengalami seperti Eleador Roosevelt dan Harry S.Truman.

\section{TELAAH KRITIS TERHADAP PSIKOLOGI MODERN}

Konsep-konsep, metodologi dan pendekatan-pendekatan dalam psikologi yang telah dirumuskan para ahli bukanlah suatu capaian final. Selalu terkandung cacat atau kelemahan dari setiap rumusan dan ilmu. Telaah kritis akan diarahkan kepada psikologi modern yang sudah diakui sebagai psikologi yang mapan yaitu psikoanalisis, behaviorisme dan psikologi humanistik.

\section{Kritik terhadap Behaviorisme}

Pandangan ini memberi penekanan yang sangat besar terhadap aspek stimulasi lingkungan untuk mengembangkan manusia dan kurang menghargai bakat atau potensi alami manusia. Lingkungan yang buruk akan menghasilkan manusia yang buruk begitu sebaliknya. Kritik terhadap aliran ini dapat diarahkan pada pengingkaran terhadap potensi alami manusia. Ketika bayi lahir sudah tampak perbedaan diantara bayi yang satu dengan yang lain seperti bayi yang pandai tersenyum dan ada pula bayi yang lebih suka mengatupkan bibirnya. Perbedaan individual adalah sebuah kenyataan yang diingkari oleh Behaviorisme.

Disamping itu aliran ini cenderung untuk mereduksi manusia. Prilaku manusia yang sangat unik dan majemuk tak ubahnya laksana mesin yang bekerja karena menerima faktor-faktor penguat berupa ganjaran dan hukuman. Kritik lain adalah menganggap manusia sebagai makkhluk hedonis yang mempunyai motif tunggal untuk menyesuaikan diri dengan lingkungan fisik dan lingkungan sosial dengan sikap mementingkan kekinian dan kesinian (now and here).

\section{Kritik terhadap Psikoanalisis}

Teori Freud yang mengungkapkan bahwa satu-satunya hal yang mendorong kehidupan manusia adalah dorongan id (libido seksualitas) adalah 
teori yang menimbulkan tantangan keras. Dalam libido seksualitas, seseorang mempertahankan eksistensinya karena bermaksud memenuhi hasrat seksualnya. Dalam psikologi humanistik, Pandangan ini hanya dapat menjelaskan kebutuhan manusia yang paling mendasar yaitu kebutuhan fisiologi dan tak mampu memberikan penjelasan tentang empat kebutuhan manusia yang lain. Teori Freud akan kesulitan menjelaskan tentang kebutuhan manusia tentang aktualisasi atau juga kebutuhan untuk beragama. Konsep Psikoanalisis terlalu menekankan pengaruh masa kecil terhadap perjalanan manusia. Setelah seorang mengalami masa kecil yang kelam seakan-akan tidak ada lagi harapan baginya untuk hidup secara normal. Pandangan ini terkandung pesimisme yang besar pada setiap upaya pengembangan diri manusia.

\section{Kritik terhadap Humanistik}

Karena adanya keragu-raguan terhadap Psikoanalisis dan aliran prilaku, maka sejumlah ahli menganjurkan untuk memperhatikan aliran ketiga yaitu Humanistik. Aliran yang dipelopori oleh Abraham H.Maslow dan Cart Ransom Rogers ini sangat menghargai keunikan pribadi, penghayatan subyektif, kebebasan, tanggung jawab, dan terutama kemampuan untuk mengaktualisasikan diri pada setiap individu. Akhirnya begitu banyak psikolog muslim yang terpesona dengan psikologi Humanistik. Bahkan sebagai psikolog muslim menganggap psikologi Humanistis mewakili suara Islam. Pandangan ini tidak menekankan dan mendewakan masalah kuantitatif, mencoba tidak terpenjara oleh dualisme subyek-obyek dan mengakui kesamaan akan manusia. Akan tetapi jika ditelaah lebih lanjut akan ditemui banyak kejanggalan. Pandangan ini sangat optimistik dan bahkan terlalu optimistik terhadap upaya pengembangan sumber daya manusia sehingga manusia dipandang sebagai penentu tunggal yang mampu melakukann playGod (peran Tuhan).

\section{INTEGRASI PSIKOTERAPI DAN ISLAM}

Di kalangan ahli psikologi dan psikiatri hasrat untuk membantu mengatasi problem kejiwaan kini berkembang sangat pesat seiring banyak berkembangnya macam-macam teknik psikoterapi. ${ }^{5}$ Kelompok lainnya yang bergelut dengan usaha mengatasi gangguan jiwa adalah para agamawan. Sejauh ini kelompok aliran psikologi/psikiatri dan agamawan belum menyatu di dalam kegiatan mereka. Para ahli psikologi/psikiatri banyak yang belum mengakui eksistensi agama sebagai salah satu pendekatan dalam penyembuhan gangguan jiwa. Hal ini disebabkan adanya pemikiran bahwa agama tidak termasuk dalam bidang ilmu pengetahuan. Pembahasan selanjutnya yaitu untuk melihat hubungan antara apa yang diajarkan oleh

\footnotetext{
${ }^{5}$ Corsini, R. (Ed.), Current Psychotherapy. Ithaca, III: FE. Peackock Publisher Inc.
} 
agama (Islam) dan ilmu pengetahuan dengan kaitannya dengan kesehatan jiwa.

\section{Apakah gangguan jiwa itu?}

Salah satu definisi gangguan jiwa dikemukakan oleh Frederick H. Kanfer dan Arnold P.Goldstein. Menurut kedua ahli tersebut, gangguan jiwa adalah kesulitan yang dihadapi oleh seseorang karena hubungannya dengan orang lain, kesulitan tentang persepsinya tentang kehidupan dan sikapnya terhadap dirinya sendiri. Ciri-cirinya sebagai berikut:

Pertama, hadirnya perasaan cemas (anxiety) dan perasaan tegang (tension) di dalam diri.

Kedua, merasa tidak puas (dalam artian negatif) terhadap diri sendiri.

Ketiga, ketidakmampuan untuk berfungsi secara efektif didalam menghadapi problem.

Keempat, perhatian yang lebih-lebih terhadap probem yang dihadapi.

Terkadang ciri tersebut tidak dirasakan penderita yang merasakan akibat dari prilaku penderita adalah masyarakat di sekitarnya. ${ }^{6}$

\section{Sebab-sebab gangguan jiwa}

Penyebab gangguan kejiwaan bermacam-macam, ada yang bersumber dari hubungan dengan orang lain yang tidak memuaskan (seperti diperlakukan tidak adil, semena-mena, cinta tidak terbalas), kehilangan seseorang yang dicintai, pekerjaan dll. Selain itu ada gangguan jiwa yang disebabkan oleh faktor-faktor organik, kelainan sistem syaraf dan gangguan otak. Para ahli psikologi berbeda pendapat tentang sebab-sebab terjadinya gangguan jiwa. Menurut pendapat Sigmund Freud gangguan jiwa terjadi karena tidak dapat didamaikannya tuntutan Id (dorongan instinktif yang bersifat seksual) dengan tuntutan super ego (tuntunan norma sosial). Orang ingin berbuat sesuatu yang dapat memberikan kepuasan diri, akan tetapi perbuatan tersebut akan membawa celaan masyarakat. Konflik yang tidak terselesaikan antara keinginan diri dan tuntutan masyarakat ini akhirnya akan mengantarkan orang apada gangguan jiwa.

Ahli lain Henry A.Murray dan Abraham H.Maslow, menurut mereka apabila manusia tidak dapat memenuhi kebutuhan hidupnya maka ia akan mengalami gangguan jiwa. ${ }^{7}$ Ada lima kebutuhan yang dikemukakan oleh Maslow dari tingkatan yang paling rendah hingga tingkatan yang paling tinggi. Pertama, kebutuhan fisiologis yaitu kebutuhan dasar yang harus dipenuhi oleh setiap manusia untuk hidup seperti makan, minum dan istirahat. Orang tidak akan memikirkan kebutuhan lainnya sebelum kebutuhan dasar ini

6 Psikoterapi dan gangguan jiwa selengkapnya dapat dibaca dalam M.Hamdani Bakran Adz-Dzaky, Psikoterapi dan Konseling Islam, penerapan metode sufistik, (Yogyakarta: Fajar Pustaka Baru, 2002), hal.219.

${ }^{7}$ Ramayulis, Psikologi Agama... hal.163. 
terpenuhi. Kedua, kebutuhan akan rasa aman (safety). Setelah orang dapat memenuhi kebutuhan dasar selanjutnya berkembang untuk memenuhi rasa aman. Orang ingin bebas dari rasa takut dan cemas. Manifestasi dari kebutuhan ini antara lain adalah perlunya tempat tinggal yang permanen, pekerjaan yang permanen. Bila kebutuhan ini telah terpenuhi selanjutnya akan muncul kebutuhan lain.

Ketiga, kebutuhan akan rasa kaih sayang. Perasaan memiliki dan dimiliki oleh orang lain atau sekelompok masyarakat adalah sesuatu yang dibutuhkan oleh manusia. Kebutuhan akan terpenuhi apabila ada saling perhatian, saling kunjung mengunjungi sesama anggota masyarakat dan keintiman dalam pergaulan akan menyuburkan kebutuhan ini. Keempat, kebutuhan akan harga diri. Pada tingkatan ini manusia ingin dihargai dirinya sebagai manusia dan sebagai warga negara. Kelima, kebutuhan akan aktualisasi diri. Ini merupakan kebutuhan yang paling tinggi. Pada tingkatan ini manusia ingin berbuat sesuatu semata-mata keinginan dari dalam dirinya. Dia tidak lagi menuntut penghargaan dari orang lain apa yang telah dia perbuat. Sesuatu yang akan dikejar dalam kebutuhan ini adalah keindahan, kesempurnaan keadilan dan kebermaknaan.

Selain pendapat yang dikemukakan diatas, menurut Alfred Adler gangguan jiwa disebabkan oleh tekanan dari perasaan rendah diri (inferiority complex) yang berlebih-lebihan. Timbulnya rasa rendah diri adalah kegagalan di dalam mencapaii superioritas di dalam hidup. Kegagalan yang terus menerus akan menyebabkan kecemasan dan ketegangan emosi. Dari pendapat-pendapat tentang penyebab terjadinya gangguan jiwa seperti yang dikemukakan diatas dapat disimpulkan bahwa gangguan jiwa disebabkan oleh ketidakmampuan manusia dalam mengatasi konflik dalam diri, tidak terpenuhi kebutuhan hidup, perasaan kurang diperhatikan (kurang dicintai) dan perasaan rendah diri.

Dalam agama islam keterpisahan antara ilmu pengetahuan dan masalah agama tidaklah terjadi. Agama dan ilmu pengetahuan berjalan seiring dan tidak terpisahkan. Oleh karena itu untuk membuat pemisahan antara pendekatan psikologi (yang bebas agama) sebagai ilmu pengetahuan dan agama sebagai teknik terapi adalah tidak mungkin. Salah satu ayat al-Qur'an yang berisikan aspek penyembuhan jiwa adalah Surat Yunus ayat 57:

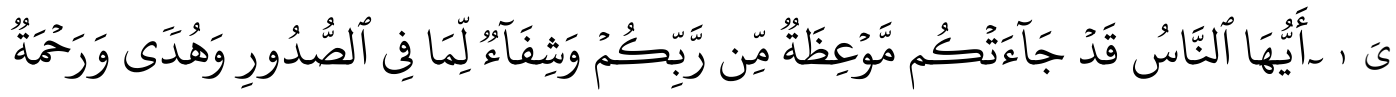

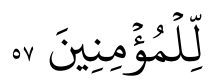




\section{Artinya:}

Hai manusia, Sesungguhnya Telah datang kepadamu pelajaran dari Tuhanmu dan penyembuh bagi penyakit-penyakit (yang berada) dalam dada dan petunjuk serta rahmat bagi orang-orang yang beriman.

Ayat diatas menunjukkan bahwa agama itu sendiri berisikan aspek terapi bagi gangguan jiwa. Bukankah penderita batin biasanya akan menyesakkan dada seperti yang tersirat dalam ayat tersebut?. Banyak sekali ayat yang isinya sejalan dengan ayat diatas. Misalnya Surat al-Isra' ayat 82.

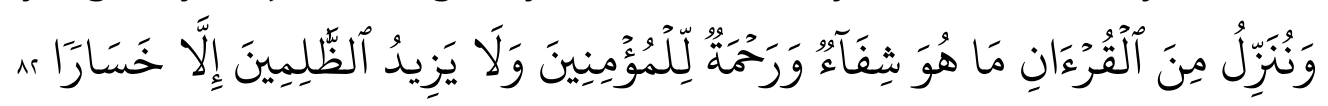

\section{Artinya :}

Dan kami turunkan dari Al Quran suatu yang menjadi penawar dan rahmat bagi orang-orang yang beriman dan Al Quran itu tidaklah menambah kepada orangorang yang zalim selain kerugian.

Ayat-ayat diatas memberi petunjuk bahwa agama mempunyai sifat terapeutik bagi gangguan jiwa. Namun bagaimanakah pelaksanaanya tersebut haruslah dilihat dari ajaran-ajaran agama islam itu sendiri sebagai contoh adalah ajaran sholat.

\section{SHALAT DAN KESEHATAN JIWA}

Peranan sholat bagi kesehatan jiwa sudah banyak dikupas oleh beberapa penulis. Ada empat aspek terapeutik yang terdapat dalam sholat yaitu aspek olah raga, aspek meditasi, aspek auto-sugesti dan aspek sugesti. Sebenarnya rukun Islam lainnya seperti puasa, haji, zakat, membaca dua kalimah syahadat juga memiliki aspek terapeutik, namun pada pembahasan ini khusus kegiatan sholat. ${ }^{8}$ Aspek terapeutik meliputi:

Aspek olah raga, sholat adalah proses yang menuntut suatu aktivitas fisik. Konstraksi otak, tekanan dan message pada bagian otot-otot tertentu dalam pelaksanaan sholat merupakan suatu proses relaksasi. Eugene Walker melaporkan hasil penelitian yang menunjukkan bahwa olah raga dapat mengurangi kecemasan jiwa. Jika dikaitkan dengan sholat yang penuh dengan aktivitas fisik dan ruhani, khususnya sholat yang banyak rakaatnya maka tidak dapat dipungkiri bahwa sholat pun akan dapat menghilangkan kecemasan.

Aspek meditasi, sholat adalah proses yang menuntut konsentrasi yang dalam. Setiap muslim dituntut untuk melakukan hal tersebut yang dalam bahasa Arabnya disebut dengan khusuk. Kekhusukan di dalam sholat tersebut adalah proses meditasi sedangkan meditasi dapat menghilangkan kecemasan.

Aspek auto-sugesti, bacaan dalam sholat adalah ucapan yang dipanjatkan pada Allah. Disamping berisi pujian pada Allah juga berisikan doa

${ }^{8}$ Agama dan Kesehatan Mental selengkapnya dapat dibaca dalam Zakiah Daradjat, Kesehatan Mental, (Jakarta: UIN Syarif Hidayatullah, 1984) 
dan permohonan kepada Allah agar selamat dunia dan akhirat. Ditinjau dari teori hipnotis yang menjadi landasan dari salah satu teknik terapi kejiwaan, pengucapan kata-kata itu berisikan suatu proses auto-sugesti. Mengatakan hal-hal yang baik terhadap diri sendiri adalah mensugesti diri sendiri agar memiliki sifat yang baik tersebut.

Aspek kebersamaan, dalam melaksanakan sholat sangat disarankan oleh agama untuk melakukan secara berjamaan. Ditinjau dari aspek psikologi kebersamaan itu sendiri memberikan aspek terapeutik. Akhir-akhir ini berkembang terapi yang disebut terapi kelompok yang bertujuan untuk menimbulkan suasana kebersamaan. Beberapa ahli psikologi berpendapat bahwa perasaan keterasingan dari orang lain adalah penyebab utama terjadinya gangguan jiwa. Dengan sholat berjamaah perasaan terasing dari orang lain akan hilang. Selain memberikan terapi yang bersifat kuratif, agama juga memiliki aspek preventif terhadap gangguan jiwa. Adanya perintah Allah untuk menjaga persaudaraan sesama manusia, saling memenuhi kebutuhan, saling merasakan penderitaan dan kesenangan orang lain akan menjaga dari terjadinya gangguan jiwa.

\section{KONSEP PSIKOLOGI ISLAM TENTANG MANUSIA}

Apakah dan siapakah manusia? Pertanyaan klasik ini selalu menarik untuk dijawab oleh umat manuia sepanjang zaman. Pembahasan ini mencoba menelaah bagaimana pandangan psikologi modern tentang manusia dan pandangan psikologi islami tentang manusia.

\section{Manusia sebagai obyek study}

Konsep manusia dalam disiplin-disiplin ilmu pengetahuan modern adalah konsep sentral. Jika kita masuk dalam kajian-kajian psikologi, sosiologi, antropologi, ekonomi, hukum, manajemen, sastra, filsafat ilmu pengetahuan dan teologi, maka konsep-konsep manusia selalu menjadi faktor utama karena memegang peranan penting dalam mengembangkan suatu teori atau disiplin ilmu. Konsep manusia ini akan menentukan bagaimana penelitian terhadap manusia dilakukan dan bagaimana perlakuan terhadap manusia dilangsungkan.

Begitu juga jika kita menelaah psikologi, maka setiap aliran, teori dan sistem psikologi senantiasa berakar pada sebuah pendangan filsafat tentang manusia, apakah manusia itu. Seperti konsep-konsep manusia dalam pandangan aliran-aliran psikologi modern (psikoanalisis, humanistik dan behavioristik) yang setelah dilakukan analisis mempunyai kekurangan masing-masing yang telah dibahas pada bagian sebelumnya. 


\section{Konsep Psikologi Islam Tentang Ciri-ciri Manusia}

Membicarakan manusia adalah membicarakan sesuatu hal yang sulit, karena banyak persoalan yang terkandung dalam diri manusia itu. Namun upaya merumuskan pandangan tentang manusia dapat dilakukan dengan merujuk pada al-Qur'an dan al-Hadits. Menurut Hanna Djumhana Bastaman dalam al-Qur'an wawasan tentang manusia adalah:

a) Manusia mempunyai derajat yang sangat tinggi sebagai Khalifah

b) Manusia tidak menanggung dosa asal atau dosa turunan

c) Manusia merupakan kesatuan dari empat dimensi; fisik-biologis, mantalpsikis, sosio-kultur, dan spiritual.

d) Dimensi spiritual (Ruhani, Ruh-ku) memungkinkan manusia mengadakan hubungan dengan Tuhan melalui cara-cara yang diajarkan-Nya.

e) Manusia memiliki kebebasan berkehendak (freedom of will) yang memungkinkan mengarahkan manusia kearah keluhuran atau kesesatan.

f) Manusia mempunyai akal sebagai kemampuan khusus dan dengan akalnya manusia mengembangkan ilmu pengetahuan.

g) Manusia tak dibiarkan hidup tanpa bimbingan dan petunjuk-Nya.

Tugas utama manusia di bumi disamping sebagai Abdullah (hamba Allah) adalah sebagai khalifah. Agar manusia dapat menjalankan tugas kekhalifahan dengan baik maka manusia dilengkapi potensi-potensi yang memungkinkannya dapat memikul tugas tersebut. Potensi tersebut diantaranya:

Ciri Pertama, manusia mempunyai raga dengan bentuk yang sebaikbaiknya. Dengan fisik yang bagus diharapkan manusia bersyukur kepada Allah.

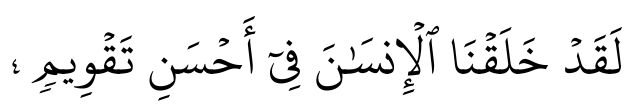

\section{Artinya:}

Sesungguhnya kami Telah menciptakan manusia dalam bentuk yang sebaikbaiknya.

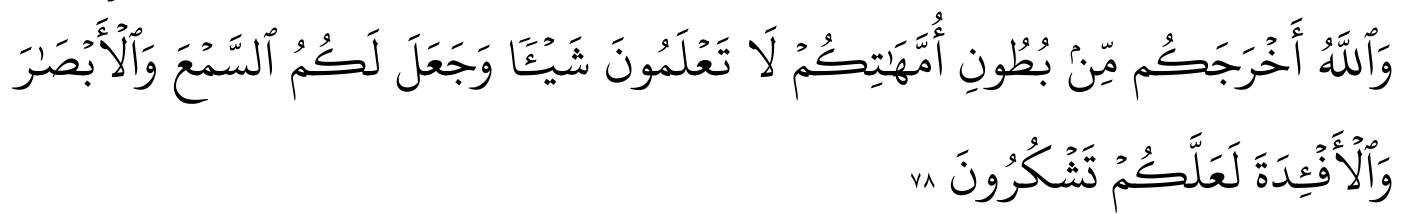

\section{Artinya:}

Dan Allah mengeluarkan kamu dari perut ibumu dalam keadaan tidak mengetahui sesuatupun, dan dia memberi kamu pendengaran, penglihatan dan hati, agar kamu bersyukur.

Ciri kedua, manusia itu bersifat baik dari segi fitrah sejak semula. Manusia tidak mewarisi dosa asal karena Adam dan Hawa keluar dari surga. Salah satu ciri utama fitrah adalah menusia menerima Allah sebagai Tuhan. 
Sebab-sebab yang menjadikan seseorang tidak percaya terhadap Tuhan bukanlah sifat dari asalnya, tetapi ada kaitannya dengan alam sekitarnya. Konsep Islam ini bertentangan dengan kristen tentang dosa asal dan konsep Behaviorisme yang menganggap manusia itu netral.

Ciri ketiga adalah ruh. Al-Qur'an secara tegas mengatakan bahwa kehidupan manusia tergantung pada wujud ruh dalam badannya. Tentang bagaimana wujudnya, bagaimana bentuknya dilarang untuk mempersoalkannya. Tentang ruh Al-Qur'an menyatakan bahwa tingkah laku manusia adalah akibat dari interaksi antara ruh dan badan. Dalam al-Quran Surah al-Hijr:29, "Maka apabila Aku Telah menyempurnakan kejadiannya, dan Telah meniupkan kedalamnya ruh (ciptaan)-Ku, Maka tunduklah kamu kepadanya dengan bersujud".

Ciri keempat adalah kebebasan kemauan atau kebebasan berkehendak yaitu kebebasan untuk memilih tingkah lakunya sendiri, kebaikan atau keburukan. Sebagai khalifah manusia menerima dengan kemauan sendiri amanah yang tidak dapat dipikul oleh makhluk-makhluk lain. Dalam Q.S alKahfi:29, "Dan Katakanlah: "Kebenaran itu datangnya dari Tuhanmu; Maka barangsiapa yang ingin (beriman) hendaklah ia beriman, dan barangsiapa yang ingin (kafir) Biarlah ia kafir...". Artinya manusia boleh menerima dan menolak untuk percaya kepada Allah, dia memiliki kebebasan berkehendak.

Ciri yang kelima adalah akal. Akal dalam pengertian Islam bukanlah otak, melainkan daya fikir yang terdapat dalam jiwa manusia. Akal dalam Islam merupakan ikatan dari tiga unsur yaitu pikiran, perasaan dan kemauan. Menurut T.M. Usman El-Muhammady, bila ikatan itu tidak ada. Akal adalah alat yang menjadikan manusia dapat melakukan pemilihan antara yang betul dan yang salah. Allah selalu memerintahkan manusia untuk menggunakan akalnya agar dapat memahami fenomena alam semesta. Akan tetapi disadari bahwa akal manusia punya keterbatasan.

Ciri keenam adalah nafsu. Nafs atau nafsu seringkali dikaitkan dengan gejolak atau dorongan yang terdapat dalam diri manusia. Apabila dorongan itu berkuasa dan manusia tidak mengendalikannya maka manusia akan tersesat. Dalam Q.S al-Furqan :43-44

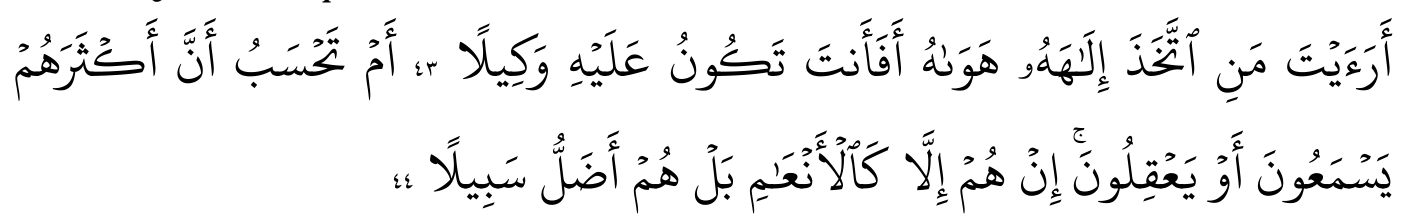

Artinya:

43. Terangkanlah kepadaku tentang orang yang menjadikan hawa nafsunya sebagai Tuhannya. Maka apakah kamu dapat menjadi pemelihara atasnya? 
44. Atau apakah kamu mengira bahwa kebanyakan mereka itu mendengar atau memahami. mereka itu tidak lain, hanyalah seperti binatang ternak, bahkan mereka lebih sesat jalannya (dari binatang ternak itu).

Kesesatan tersebut terjadi karena manusia yang dikuasai nafsunya itu tidak menggunakan hati dan indra yang dimilikinya (Q.S 7:178-179) agar nafsu selalu dalam naungan kebenaran, maka manusia harus selalu beristiqamah/berteguh pendirian terhadap Allah, selalu ikhlas dalam setiap amal dan selalu ingat bahwa diri ini akan kembali kepada-Nya. Dalam Q.S alA'raf: 178-179,

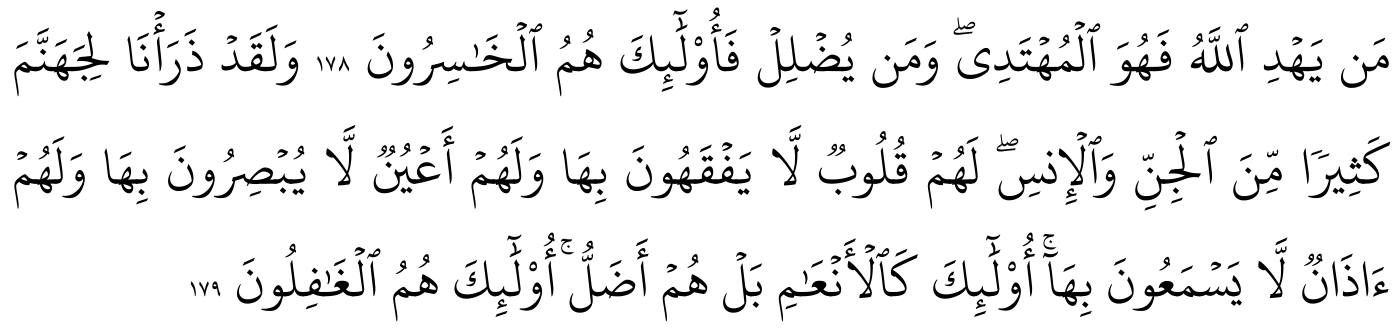

\section{Artinya:}

178. Barangsiapa yang diberi petunjuk oleh Allah, Maka dialah yang mendapat petunjuk; dan barangsiapa yang disesatkan Allah, Maka merekalah orangorang yang merugi.

179. Dan Sesungguhnya kami jadikan untuk (isi neraka Jahannam) kebanyakan dari jin dan manusia, mereka mempunyai hati, tetapi tidak dipergunakannya untuk memahami (ayat-ayat Allah) dan mereka mempunyai mata (tetapi) tidak dipergunakannya untuk melihat (tanda-tanda kekuasaan Allah), dan mereka mempunyai telinga (tetapi) tidak dipergunakannya untuk mendengar (ayatayat Allah). mereka itu sebagai binatang ternak, bahkan mereka lebih sesat lagi. mereka Itulah orang-orang yang lalai.

\section{Fitrah: Konsep Utama dalam Psikologi Islam}

Sehubungan dengan kata fitrah ada sebuah hadist shohih yang sangat populer dikalangan ahli pendidikan mengenai hal ini, yaitu hadist yang diriwayatkan dari Abu Hurairah ra. Rosulullah saw. bersabda:

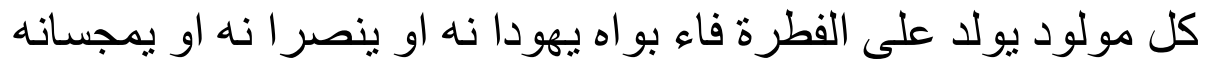

Artinya:

"Setiap anak dilahirkan dalam keadaan fitrah (yaitu suci dan bersih). Kedua orang tuanyalah yang menjadikan Yahudi, Nasrani, atau Majusi". (H.R. Muslim).

Menurut Ahmad Tafsir, dalam hadist ini manusia lahir membawa kemampuan-kemampuan atau pembawaan. Fitrah yang disebutkan di dalam hadist ini adalah potensi. Potensi adalah kemampuan, jadi fitrah yang dimaksud disini adalah pembawaan. ${ }^{9}$ Demikian pula Hasan Langgulung,

9 Ahmad Tafsir, Ilmu Pendidikan dalam Perspektif Islam, (Bandung: PT Remaja Rosdakarya, 1991), hal. 35. 
memaknai hadist diatas fitrah adalah potensi yang baik. ${ }^{10}$ Sebab pengertian hadist diatas menjadikan Yahudi, Nasrani dan Majusi itu bermakna menyesatkan. Makna bapak dan ibu adalah lingkungan sebagaiman yang dimaksud oleh para ahli pendidikan. Keduanyalah yang menetukan perkembangan seseorang.

Dalam Q.S Al-Rum:30 dijelaskan lebih lanjut hakikat fitrah ini dengan firman-Nya:

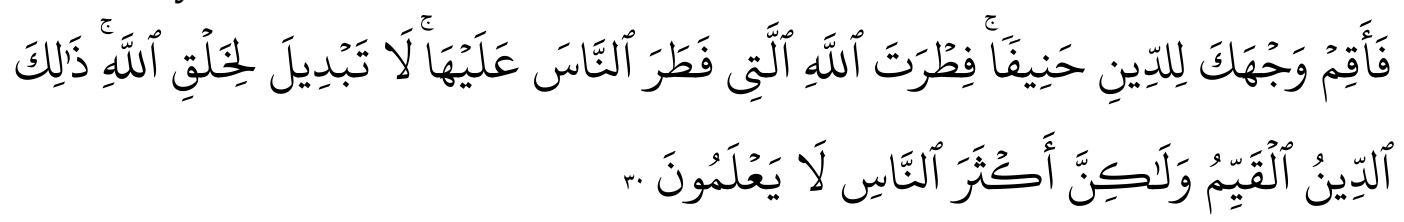

\section{Artinya:}

"Hadapkanlah wajahmu dengan lurus pada agama (Allah Swt), (tetaplah atas) fitrah Allah. Yang telah menciptakan manusia menurut fitrah itu. Tidak ada perubahan atas fitrah Allah Swt. (Itulah) agama yang lurus, tetapi kebanyakan orang tidak mengetahuinya". (Q.S Al-Rum (30):30) ${ }^{11}$

Makna Fa aqim wajhaka li ad-din hanifa (Hadapkannlah wajahmu dengan lurus pada agama Allah Swt). Menurut Mujahid, Ikrimah, al-Jazairi, Ibnu al-"Athiyah, Abu al-Qosim al-Kalbi dan az-Zuhayli, kata ad-din bermakna din al-Islam.12 Penafsiran ini sangat tepat karena ayat ini ditujukan kepada Rosulullah Saw, tentu agama yang dimaksud adalah Islam. Adapun hanif adalah cenderung pada jalan yang lurus dan meninggalkan kesesatan. Dengan demikian, perintah untuk mengharuskan untuk menghadapkan wajah pada din al-Islam dengan pandangan lurus; tidak menoleh ke kiri dan ke kanan, dan tidak condong pada agama-agama lain yang batil dan menyimpang. Penerimaan merupakan sikap menerima secara total terhadap agama, istiqomah didalamnya, teguh terhadapnya dan memandangnya amat penting.

Seperti yang sudah disampaikan, bahwa pengertian fitrah terkait dengan pengertian hanif. Manusia yang sudah kembali menemukan fitrahnya, ia akan terkondisikan untuk menjadi hanif. Kata hanif berasal dari kata kerja hanafa, yahnifu dan masdarnya hanifan, artinya adalah "condong", atau "cenderung" dan kata bendanya "kecenderungan". Dalam Alqur'an, kata hanif yang dimaksud adalah "cenderung kepada yang benar". Setelah orang selalu tertambat hatinya kepada kebenaran (hanif) dan menolak dengan keras segala bentuk penentangan dan persekutuan terhadap Allah.

Dapat disimpulkan bahwa inti fitrah adalah bahwa manusia memiliki kecenderungan beragama, lebih spesifik lagi adalah islam, iman dan tauhid.

${ }^{10}$ Hasan Langgulung, Pendidikan dan Peradaban Islam, (Jakarta: PT Maha Grafindo, 1985), hal. 214.

${ }^{11}$ Al-Qur'an dan Terjemahannya, (Kudus: Menara Kudus)

12 Dikutip dalam Abd. Rachman Assegaf, Filsafat Pendidikan Islam, (Jakarta: P.T Raja Grafindo Persada, 2011).hal. 50. 
Fitrah manusia adalah sesuatu kekuatan atau kemampuan (potensi terpendam) yang menetap pada diri manusia sejak awal kejadiannya sebagai sifat kodrati, untuk komitmen terhadap keimanan kepada-Nya, cenderung kepada hanif (kebenaran), dan potensi itu merupakan ciptaan Allah. Fitrah Allah berarti ciptaan Allah. Manusia diciptakan Allah mempunyai naluri beragama, yaitu agama Tauhid; maka hal itu tidak wajar kalau manusia tidak beragama tauhid. Mereka tidak beragama tauhid itu hanya lantaran pengaruh lingkungan.

Dengan konsep fitrah ini maka kita dapat mengatakan bahwa konsep Islam tentang manusia berbeda bahkan bertentangan dengan konsep psikologi barat (Psikoanalisis, Behaviorisme dan Humanisme). Islam juga menolak anggapan bahwa ketika dilahirkan manusia dalam keadaan netral (nol).

\section{SIKAP KONTRA TERHADAP PSIKOLOGI ISLAM}

Psikologi Islam memiliki kedudukan yang sama dengan disiplin ilmu keislaman yang lain, seperti sosiologi Islam, ekonomi Islam, dan sebagainya. Penggunaan kata "Islam" disini memiliki arti corak, cara pandang, pola pikir, paradigma, atau aliran-aliran tersendiri yang berbeda dengan psikologi kontemporer pada umumnya. Psikologi Islam tidak hanya menekankan perilaku kejiwaan, melainkan juga hakekat jiwa sesungguhnya.

Sebagai satu organisasi permanen, jiwa manusia bersifat potensial yang aktualisasinya dalam bentuk perilaku sangat tergantung pada ikhtiarnya. Dari sini nampak bahwa psikologi Islam mengakui adanya kesadaran dan kebebasan manusia untuk berkreasi, berpikir, berkehendak, dan bersikap secara sadar, walaupun kebebasan itu tetap dalam koridor sunnah-sunnah Allah SWT. Psikologi Islam mempunyai tujuan yang hakiki, yaitu merangsang kesadaran diri agar mampu membentuk kualitas diri yang lebih sempurna untuk kebahagiaan di dunia dan di akhirat. ${ }^{13}$

Menurut Muhammad Izzudin Taufiq, ada tiga sikap dan respon yang ditunjukkan terhadap proyek rekontruksi Islami untuk studi kejiwaan yaitu: ${ }^{14}$ Pertama, sikap yang menentang dari kalangan Islam. Pendapat ini umumnya dimunculkan kaum muslimin yang berpendapat bahwa Islam sangat kaya dan tidak membutuhkan rekontruksi apapun, ini terjadi setelah sebagian kaum muslimin itu mempelajari psikologi dan melihat dampaknya pada kaum mudamudi, bahkan kaum terpelajar sekalipun.

Kedua, sikap yang menentang dari kalangan psikologi. Kelompok ini berasal dari psikolog-psikolog muslim yang banyak memahami psikologi

13 Abdul Rahman Shaleh, Psikologi Suatu Pengantar dalam Perspektif Islam, ( Jakarta: Kencana, 2008), hal.23.

14 Muhammad Izzudin Taufiq, Panduan Lengkap dan Praktis Psikologi Islam, Sari Narulita, Dkk, (terj.) (Depok:Gema Insani, 2006), 15 dan 80. 
Barat dan kurang memahami Islam sehingga membuat mereka lebih cenderung pada spesialisasi ilmiah dan profesi yang mereka geluti, mereka lebih bersandar pada filsafat Barat yang membedakan hubungan ilmu pengetahuan dan agama. Ketiga, sikap yang menerima pemikiran rekontruksi dan aktivitas untuk mewujudkannya. Dalam kaitan proyek rekontruksi Islam dalam studi kejiwaan ada beberapa hal yang perlu dicatat; bukan hanya menyisipkan akhlak Islami yang seyogyanya dimiliki oleh para ilmuwan muslim, bukan hanya ayatisasi atau memberi kajian hadis pada hal-hal yang berkaitan dengan jiwa yang dikumpulkan dan ditasirkan kemudian dikomparasikan dengan teori-teori yang ada dalam kajian psikologi, bukan sekedar kurikulum dalam psikologi yang menganalisis ayat al-qur'an, al-hadis, yang kemudian diberi label psikologi Islam.

Djamaludin Ancok ${ }^{15}$ berpendapat bahwa setiap orang mempunyai hak sepenuhnya dalam membangun keilmuan baru misalnya psikologi Islam yang merupakan disiplin ilmu yang masih muda dan konsep-konsep yang terbangun belum tersistematis dengan baik. Oleh karena itu sejauh ini konsep dasar Psikologi Islam pun masih beragam sekali wujudnya.

\section{PSIKOLOGI DAN PENDIDIKAN ISLAM}

Pendidikan Islam disini diartikan sebagai upaya sadar yang dilakukan oleh mereka yang memiliki tanggungjawab terhadap pembinaan, bimbingan, pengembangan dan pengarahan potensi yang dimiliki anak agar mereka berfungsi dan berperan sebagai hakikat kejadiannya. Dalam pelaksanaannya aktivitas pendidikan seperti diterapkan sejak usia bayi hingga ke akhir hayat, seperti tuntunan Rasul Allah saw. Dalam kaitan ini pendidikan islam erat dengan psikologi agama. Bahkan psikologi agam digunakan sebagai salah satu pendekatan dalam pelaksanaan pendidikan islam.

Rasul Allah saw menganjurkan kepada kita semua agar memberikan pendidikan harus sesuai dengan kadar kemampuan atau nalar seseorang. Dengan demikian dalam menghadapi orang yang masih awam terhadap agama berbeda dengan mereka yang sudah memiliki latar belakang pendidikan agama. Sehingga meghadapi orang dewasa harus dibedakan dengan cara menghadapi anak-anak dalam mengajarkan agama. Didiklah anak-anak dengan cara belajar sambil bermain atau bergurau pada tujuh tahun pertama dan pada tujuh tahun kedua didiklah mereka dengan disiplin dan moral,

15 Menurut Djamaludin, konsep apapun yang ditawarkan orang selalu layak untuk diperhitungkan, dikritisi dan untuk akhirnya diterima atau ditolak. Adalah hak sepenuhnya bagi kita semua membangun Psikologi Islam. Dan adalah hak mereka sepenuhnya untuk melahirkan Psikologi Transpersonal, Psikologi Indonesia, Psikologi Kristiani, Psikologi Budha dan sejenisnya. Apapun yang dilahirkan orang, setidaknya akan memperkaya khazanah ilmu dan sejarahlah yang akan membuktikan ketangguhannya. Semoga Psikologi Islam membawa perubahan bagi peningkatan kesejahteraan dan kualitas manusia, mampu membuktikan ketangguhan dalam arus gelombang sejarah dan lebih dari semua itu diridhai Allah swt. 
kemudian pada tujuh tahun berikutnya didiklah mereka dengan memperlakukan sebagai sahabat. (Muhammad Munir Mursyi, 1989,32). ${ }^{16}$

Lebih lanjut saat anak menginjak usia tujuh tahun, secara fisik mereka dibiasakan untuk menunaikan sholat (pembiasaan). Kemudian setelah mencapai usia sepuluh tahun perintah untuk menunaikan sholat secara rutin dan tepat waktu diperketat (disiplin). Pada jenjang usia inipun anak-anak diperkenankan kepada nilai-nilai ajaran agamanya. Diajarkan membaca kitab suci, sunnah rasul, maupun cerita-cerita yang bernilai pendidikan.

\section{PENUTUP}

Dari hasil analisis terhadap beberapa pembahasan diatas, dapat disimpulkan bahwa bangunan keilmuan Psikologi Islam mengacu pada suatu konsep bahwa Islam hadir dengan menawarkan pembahasan tentang konsep manusia yang lebih komprehensif. Manusia tidak hanya dikendalikan oleh masa lalu atau lingkungan yang melingkupinya, tetapi mampu merancang masa depan dan mampu mengendalikan lingkungan. Manusia disamping memiliki potensi baik juga potensi buruk (terbatas). Konsep manusia dalam Psikologi Islam adalah bio-sosiopsikis-spiritual, artinya Islam mengakui keterbatasan aspek biologis (fisiologis), mengakui peran serta lingkungan (sosiokultural), mengakui keunggulan potensi dan juga memerankan aspek spiritual (Tuhan) dalam kehidupan manusia.

Islam memandang manusia memiliki unsur jasmaniah (materi) dan ruhaniah (non-materi) yang secara umum dapat dijelaskan melalui konsep bio-sosio-psikisspiritual yang dalam perkembangan psikologi barat tidak diakui keberadaannya. Perilaku manusia terbentuk dari hasil kolaborasi semua unsur, tidak ada reduksi antar unsur sehingga pemahaman tentang manusia dapat menemukan titik temu yang utuh. Islam juga Islam menawarkan konsep manusia melalui pemahaman agama (wahyu). Memahami manusia tidak dapat dilepaskan dari konsep ruh (daya ikat pencipta dan makhluknya), hati (Qalbu) sebagai pengendali perilaku manusia, nafs yang menjadi wadah potensi manusia (baik-buruk) serta akal sebagai tempat nalar dan daya pemahaman tentang pilihan perilaku.

\section{DAFTAR PUSTAKA}

Abd. Rachman Assegaf, Filsafat Pendidikan Islam, Jakarta: P.T Raja Grafindo Persada, 2011.

Abdul Rahman Shaleh, Psikologi Suatu Pengantar dalam Perspektif Islam, Jakarta: Kencana, 2008.

16 Muhammad Munir Mursyi dikutip dalam Jalaludin, Psikologi Agama ...hal.21. 
Ahmad Tafsir, Ilmu Pendidikan dalam Perspektif Islam, Bandung: PT Remaja Rosdakarya, 1991.

Al-Qur'an dan Terjemahannya, Kudus: Menara Kudus.

Corsini, R. (Ed.), Current Psychotherapy. Ithaca, III: FE. Peackock Publisher Inc. Djamaludin Ancok \& Fuat Nashori Suroso, Psikologi Islam, Solusi Islam atas Problem-Problem Psikologi, Jakarta: Pustaka Pelajar, 2004.

Hasan Langgulung, Pendidikan dan Peradaban Islam, Jakarta: PT Maha Grafindo, 1985.

Howard S.Friedman\&Miriam W.Schustack, Kepribadian, Teori Klasik dan Riset Modern, Edisi Ketiga, Benedictine Widyasinta (terj), Jakarta: Erlangga, 2006.

Jalaluddin, Psikologi Agama, Jakarta: PT Raja Grafindo Persada, 2008.

Jalaludin Rakhmat, Psikologi Agama, sebuah pengantar, Bandung: Mizan Media Pustaka, 2005.

Kholili, Beberapa Pendekatan Psikologi Dalam Dakwah, Yogyakarta: Bidang Akademik UIN Sunan Kalijaga, 2008.

M.Hamdani Bakran Adz-Dzaky, Psikoterapi dan Konseling Islam, penerapan metode sufistik, Yogyakarta: Fajar Pustaka Baru, 2002.

Muhammad Izzudin Taufiq, Panduan Lengkap dan Praktis Psikologi Islam, Sari Narulita, Dkk, (terj.) Depok:Gema Insani, 2006.

Ramayulis, Psikologi Agama, Jakarta: Kalam Mulia, 2007.

Zakiah Daradjat, Kesehatan Mental, Jakarta: UIN Syarif Hidayatullah, 1984. 